\title{
5 \\ The vital role of environmental NGOs: Trusted brokers in complex markets
}

\section{David Freudenberger}

\section{Key lessons}

- Complex markets need brokers; eNGOs have performed this role well.

- Innovation is critical, and this requires organisations willing to fail. eNGOs are important for innovation.

- Engaging farmers is important, but sometimes it is not enough.

- Making a profit is OK.

- eNGOs provide a voice for the voiceless.

Environmental non-government organisations (eNGOs) have been actively involved in agri-environment schemes since their inception in Australia. These include a range of groups - large and small operating over a range of scales. Their role and value is sometimes overlooked in discussions on agri-environment schemes, yet their contributions are profound and often critical to the success of the scheme. In this chapter, I outline why eNGOs are so important to agri-environment schemes and list five key lessons that should always be kept in mind by the designers of future schemes. 


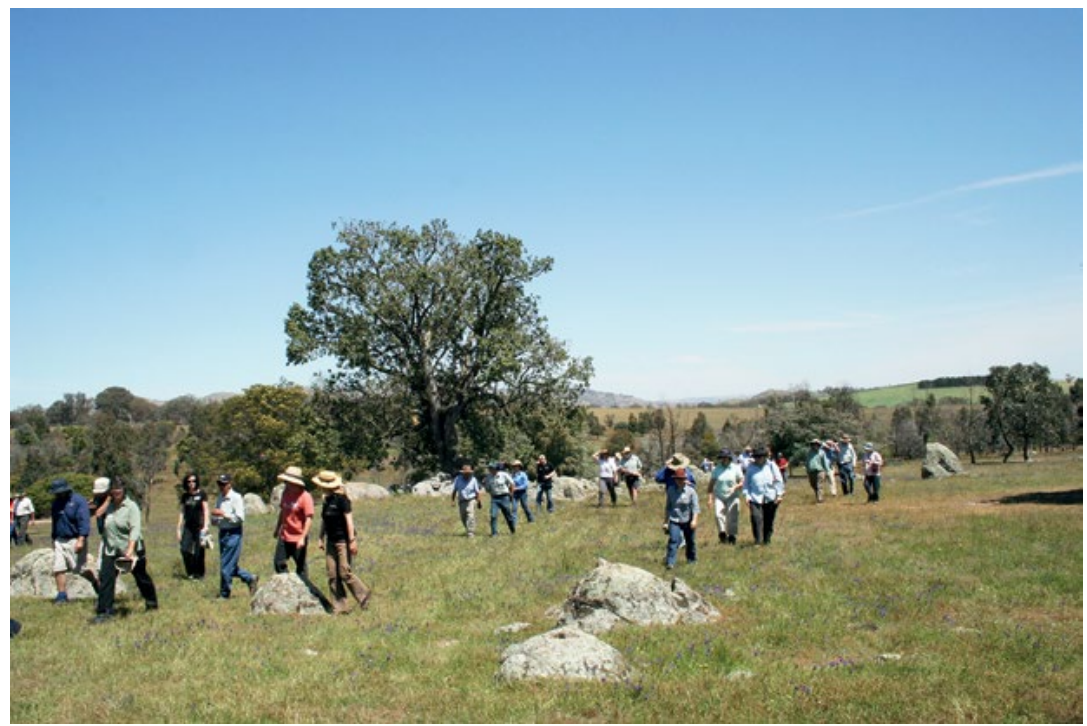

Figure 5.1: Greening Australia conducts a WOPR field day. Farmers and NRM officers are being shown over one of the first WOPR sites.

Source: Photo by David Salt.

Who are we talking about when we speak of eNGOs? At the national and international end of the scale we have organisations such as Greening Australia, Landcare Australia, Conservation Volunteers Australia, WetlandCare Australia, Birdlife Australia, World Wildlife Fund (WWF), Australian Conservation Foundation, Bush Heritage Australia, Australian Wildlife Conservancy, The Wilderness Society, and The Nature Conservancy. While all of them have an environmental dimension, they are quite different characters with different areas of focus, different people, skill sets, and modus operandi.

In addition to these large eNGOs, many hundreds of state-based, regional, and local non-government organisations have also been deeply involved with Australian agri-environment programs for over two decades. State-based organisations include trust-for-nature organisations established under state legislation in New South Wales, Victoria, and Queensland. Regional organisations include quasigovernment natural resource management (NRM) organisations, such as catchment management authorities (CMAs) in Victoria. At the local 
scale, Landcare groups and networks, many of them incorporated, have played a pivotal role in shaping and implementing government agri-environment schemes.

Over the past two decades, I have gained insights from being involved with many of these organisations operating at all scales (international to local), although I am biased by having been Chief Scientist with Greening Australia for five years (2007-2012) and having collaborated with Greening Australia as a research scientist with CSIRO. I currently collaborate with Greening Australia and Bush Heritage Australia as an academic at ANU. So here is my shortlist of insights from 20 years of being an insider and outsider to many of the eNGOs involved in Australian agri-environment schemes.

\section{Complex markets need brokers}

Agri-environment schemes are a market with essentially one buyer (the government) and a great diversity of many sellers (farmers). Australian governments essentially purchase public good environmental outcomes from many thousands of private agricultural enterprises that manage over 50 per cent of the Australian continent. Government purchases environmental outcomes primarily through direct or indirect grants to farmers. These grants generally subsidise the cost of inputs, such as planning, fencing, pest control, and revegetation (see Chapter 2 by Graham Fifield), as well as some organisational overheads. Like any buyer, the government has choices: direct one-to-one purchases of public goods from farmers, or one-tomany purchases through a diversity of brokers and arrangements. These two broad options are no different to an individual buying company shares on the stock market directly, or through the expertise (and additional cost) of a stockbroker.

A few national eNGOs, such as Greening Australia and WWF, pioneered the role of broker. Starting in the mid-1980s, they received a few large contracts from the Australian Government and delivered devolved grants to farmers through simple one-stop shop programs. These eNGOs handled the reporting obligations to the federal government; the farmers did the work on-ground, with planning advice and implementation assistance from the eNGOs. 
This brokering or facilitation role was particularly important in the early agri-environment schemes. At the time, farmers were very reluctant sellers to a distant and seemingly suspicious national government buyer, with little capacity to get staff out into the paddock and into the kitchen for a cup of tea. At one point in the mid-2000s, Greening Australia had more than 350 staff and over 30 regional offices brokering thousands of public-good environmental purchases, facilitated through many paddock walks and cups of tea. Similarly, WWF secured funding and had regional staff who facilitated the national Threatened Species Network, which help create awareness of threatened species on private land and brokered many small grants to improve their conservation.

This brokering role has generally been taken over by, at one point, 57 NRM organisations, mostly based in regional Australia and set up by state legislation and funded or co-funded by the federal government (Curtis et al. 2014). However, particularly in New South Wales, these NRM organisations have become another branch of government, as they are responsible for, among other things, the administration of land clearing legislation. It can be argued that eNGOs are rarely fully independent of government, since so many receive government funding. But they have been shaping and delivering many agri-environment schemes on behalf of Australian governments over the past 30-plus years.

The advantage of engaging a broker is the ability to build lasting relationships to help navigate the complexities and risks of entering and persisting in any market. Many eNGOs have persisted through decades of agri-environment schemes that often don't last for more than one election cycle. Continuity and organisational identity is a strength of many eNGOs. The environmental market is particularly complex, with high overheads (e.g. reporting to the government funder). Many eNGOs provide this brokerage service to government (the risk-averse buyer) and farmers (the risk-averse sellers). Without such brokers, the public good market for environmental services and outcomes would likely have been slower to develop in Australia. 


\section{Innovation: Willingness to fail}

Environmental NGOs involved in Australian agri-environment schemes have a demonstrated record of risk-taking leading to outstanding innovations. They are small enough to take on risky research and development, but large enough to survive small failures. I assert that many technical innovations in securing environmental outcomes originated from or were nurtured by a diversity of local, regional, national, and international eNGOs. Here are a few notable examples:

- Direct seeding: Direct seeding technology that has successfully reduced the cost and increased the diversity of native vegetation restoration was developed by local farmer innovators and rural engineers, facilitated and marketed by the likes of Greening Australia, with support from corporate partners and government agencies.

- Fencing: Planting fences around woodland remnants (e.g. fencing incentive schemes) rather than just planting trees was rigorously promoted to the Australian Government during the 1990s by local Landcare groups and Greening Australia, who had the capacity to lobby government in Canberra. Only later did research organisations test the effectiveness of these fencing programs to protect and enhance remnants of native vegetation (Spooner et al. 2002; Briggs et al. 2008).

- Seed production: Greening Australia made a notable contribution to the development of commercial-scale seed banks and on-farm seed production areas.

- Restoration and rehabilitation: Greening Australia facilitated the technological innovations needed to restore, at scale, speciesrich temperate grasslands (Gibson-Roy et al. 2010). The Whole of Paddock Rehabilitation (WOPR) program was invented by a farmer, but was marketed and rolled-out by Greening Australia (see Chapter 15 by Dean Ansell and Chapter 2 by Graham Fifield).

- Floodplain management: The then Murray Wetlands Working Group pioneered small-scale floodplain restoration, including the management of two environmental water licenses, recognised by the award of the prestigious National Thiess Riverprize in 2007 (www.murraydarlingwetlands.com.au). 
- Conservation planning: The Nature Conservancy played a pivotal role in introducing conservation action planning to Australia (now termed 'Open Standards for the Practice of Conservation' cmp-openstandards.org). This is a participatory planning process that is particularly effective at engaging a diversity of stakeholders in setting conservation objectives.

- Corridors: Local, regional, and international NGOs have been particularly influential in developing large-scale corridor initiatives, such as Gondwana Link (www.gondwanalink.org), Habitat $141^{\circ}$ (www.habitat141.org.au), and the Bunya Biolink (Freudenberger et al. 2013). Only much later did the federal government develop the National Wildlife Corridor Plan (www.environment.gov.au/topics/ biodiversity/biodiversity-conservation/wildlife-corridors).

As environmental brokers, eNGOs are in the position to recognise and facilitate innovation addressing local, regional, and national environmental challenges.

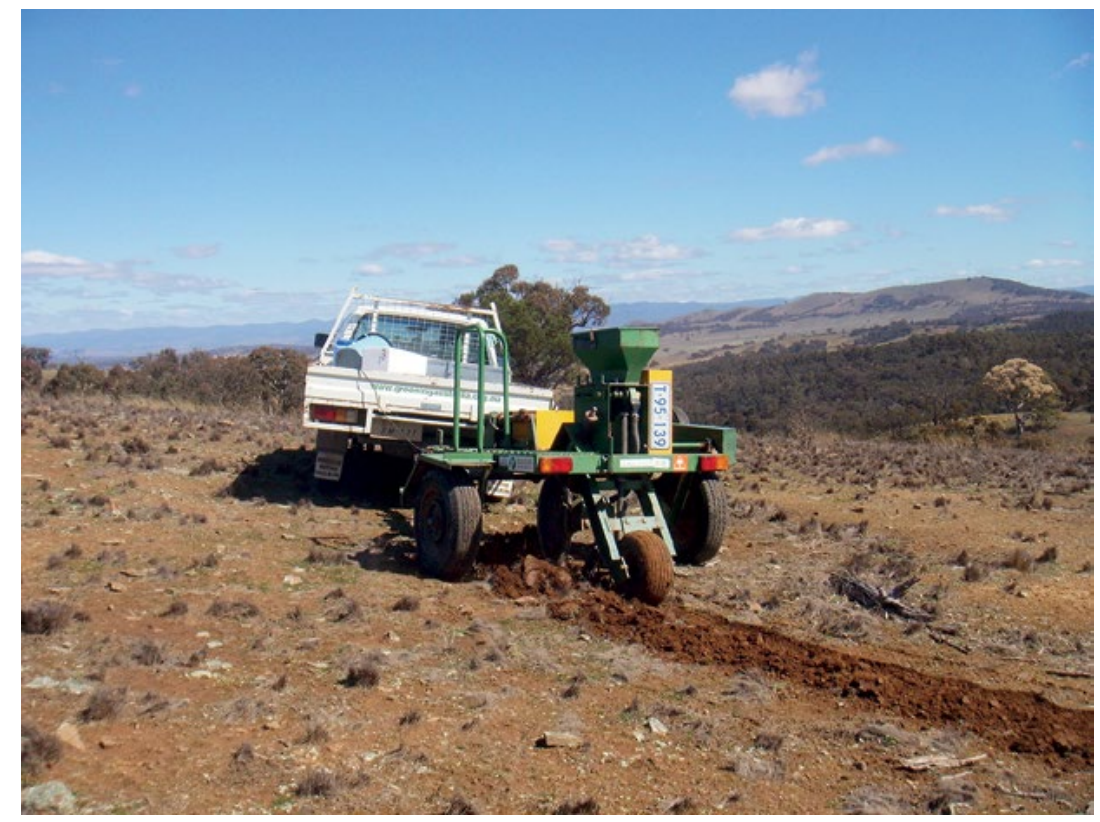

Figure 5.2: Direct seeding of trees has successfully reduced the cost and increased the diversity of native vegetation restoration.

Source: Photo by Greening Australia. 


\section{Engaging farmers is sometimes not enough}

In many agricultural landscapes, significant conservation gains cannot be achieved just by fencing off a few on-farm remnants and planting shelter belts. In places, there is a need to buy the farm and restore the lot for public good conservation outcomes.

Environmental NGOs, including the Tasmanian Land Conservancy, Bush Heritage, and Australian Wildlife Conservancy (and Greening Australia to a lesser extent), are doing just that - purchasing farms and pastoral properties in strategic locations and engaging in long-term restoration and conservation. To date, Bush Heritage Australia works across more than 4.8 million ha, including their own reserves and land owned by their partners. The Australian Wildlife Conservancy owns and manages 23 properties covering more than 3 million ha. The trusts for nature in Queensland, New South Wales, and Victoria also facilitate private investment in purchasing farmland and converting tenure to conservation in perpetuity.

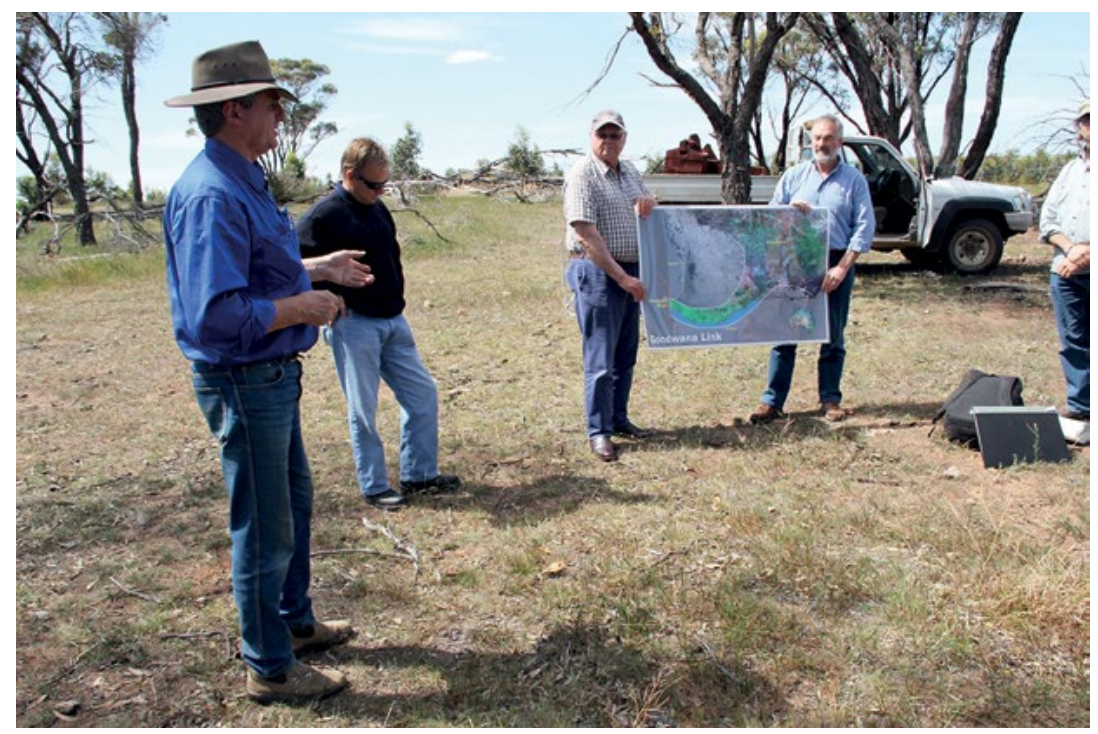

Figure 5.3: eNGOs have purchased whole properties in strategic locations in southern Western Australia. These have formed the backbone of the biolink called Gondwana Link.

Source: Photo by David Salt. 
The entrepreneurial nature of many eNGOs allow them to be free to operate at a variety of scales and locations that would be difficult for government. These agricultural land purchases and environmental management changes by eNGOs contribute to the public estate of nature reserves, but have far greater flexibility in funding, purchasing, and management than is possible for government. In general, purchases by eNGOs appear to create much less local angst than government agencies purchasing farmland on the open market. The important role of eNGOs in contributing to the national conservation estate was recognised by the Australian Government's National Reserve System Program, which co-invested in NGO conservation land purchases. For example, the National Reserve System Program has contributed more than $\$ 8$ million to Bush Heritage Australia since 1999 to assist in the purchase of 11 protected areas covering 890,000 ha. This program has also invested more than $\$ 430,000$ with the Tasmanian Land Conservancy and $\$ 6$ million to the Australian Wildlife Conservancy for land purchases (www.environment.gov.au/land/nrs/getting-involved/ conservation-organisations).

\section{Making a profit is OK}

Government and quasi-government environmental organisations are constrained by the political vagaries of annual budget allocations and zero-sum accounting (e.g. annual funding must be fully acquitted within the financial year). Environmental NGOs, as registered charities or not-for-profit businesses, can carry over funds from one year to the next. They can act as businesses and make a surplus (profit) that must be re-invested within the organisation (rather than paid out to private shareholders). NGOs can (and do) build financial reserves to support long-term strategic programs, as well as using reserves to maintain staff continuity and corporate memory (Maier et al. 2014).

Such flexibility and governance structures (e.g. boards) continue to attract philanthropic investment from individuals and foundations. Philanthropy rarely donates funds to government agencies; rather, donations to eNGOs are effective in leveraging government coinvestment (see www.abc.net.au/radionational/programs/bush telegraph/private-park-funding-slows/5888378). The history of Australian agri-environment schemes includes long-term involvement 
of philanthropy, from the early days of Potter Foundation Farmland Plan (www.ianpotter.org.au/potter-farmland-plan) to the many thousands of individual small-scale donations to eNGOs, such as the Nature Conservancy, Bush Heritage Australia, and the Australian Wildlife Conservancy actively conserving biodiversity in agricultural landscapes across Australia.

\section{A voice for the voiceless}

Environmental NGOs continue to have a significant role in lobbying governments to direct funding to the environment, including agri-environment schemes. The original National Landcare Program was initiated by a proposal arising from collaboration between the Australian Conservation Foundation and the National Farmers Federation. WWF gave a voice to Australia's highly depleted temperate grasslands and was successful in securing government funding for grassland conservation, assisted by devolved grants to farmers. NGOs have had a significant role in including farmland in Ramsarlisted wetlands, such as the Gwydir and Macquarie Marshes in central NSW. Environmental NGOs have been influential in highlighting the global significance of the Great Western Woodlands of south west Western Australia (Watson et al. 2008) and Australia's tropical savannas (Woinarski et al. 2007). Both these regions are dominated by agricultural (pastoral) uses.

As brokers between governments and private landholders, many eNGOs also provide a collective voice to progressive (green) farmers who may not be well represented by their often highly politicised state and national agricultural organisations, who are more focused on agricultural productivity issues than public good nature conservation. Many eNGOs have the time and talent to provide this voice through a myriad of conversations in capital cities where political power and funding reside.

\section{Conclusion: Still a role}

Based on my personal involvement with agri-environment schemes and eNGOs over the past 20 years, I assert that a remarkable diversity of eNGOs have shaped and continue to shape agri-environment 
schemes. These eNGOs have likewise been shaped by these schemes, largely funded by governments. These schemes would have been far less innovative, flexible, and responsive without this history of NGO involvement. eNGOs have a critical role in continuing to deliver innovation, efficiencies, and effectiveness in supporting significant public good outcomes from government investment in conservation on-farm.

\section{Acknowledgements}

The insights and opinions provided in this essay are those of the author, but are based on many conversations over the past two decades with NRM leaders, particularly those working in eNGOs, including Martin Driver, Ian Davidson, Owen Whitaker, Jaimie Pittock, David Williams, Carl Binning, David Butcher, Graham Fifield, Jonathon Duddles, Toby Jones, Robert Lambeck, Dave Carr, Keith Bradby, and Sue Streatfield. Comments from two anonymous peer reviewers have helped to sharpen and refine this essay. Thanks to you all.

\section{References}

Briggs, S.V., N.M. Taws, J.A. Seddon and B. Vanzella (2008) ‘Condition of fenced and unfenced remnant vegetation in inland catchments in south-eastern Australia', Australian Journal of Botany 56: 590-9.

Curtis, A., H. Ross, G.R. Marshall, C. Baldwin, et al. (2014) 'The great experiment with devolved NRM governance: Lessons from community engagement in Australia and New Zealand since the 1980s', Australasian Journal of Environmental Management 21: 175-99. DOI:10.1080/14486563.2014.935747.

Freudenberger, D., L. Grigg and R. Reeger (2013) 'The Bunya BioLink: An application of Greening Australia's strategic approach to large scale conservation', Linking Australia's Landscapes (eds J. Fitzsimmons, I. Pulsford and G. Wescott), CSIRO Publishing, Collingwood, pp. 153-62. 
Gibson-Roy, P., G. Moore, J. Delpratt and J. Gardner (2010) ‘Expanding horizons for herbaceous ecosystem restoration: The Grassy Groundcover Restoration Project', Ecological Management and Restoration 11: 176-86.

Maier, F., M. Meyer and M. Steinbereithner (2014) 'Nonprofit organizations becoming business-like: A systematic review', Nonprofit and Voluntary Sector Quarterly December. DOI: $10.1177 / 0899764014561796$.

Spooner, P.G., I.D. Lunt and W. Robinson (2002) 'Is fencing enough?: The short-term effects of stock exclusion in remnant grassy woodlands in southern NSW', Ecological Management and Restoration 2: 117-26.

Watson, A., S. Judd, J. Watson, A. Lam and D. Mackenzie (2008) The Extraordinary Nature of the Great Western Woodlands, Wilderness Society of WA Inc., Perth. Available at: www. wilderness.org.au/sites/default/files/media/the-great-westernwoodlands-report.pdf.

Woinarski, J., B. Mackey, H. Nix and B. Traill (2007) The nature of northern Australia: Natural values, ecological processes and future prospects, ANU E Press, Canberra. Available at: press.anu.edu.au/ nature_na/pdf/whole_book.pdf. 
This text is taken from Learning from agri-environment schemes in Australia: Investing in biodiversity and other ecosystem services on farms, edited by Dean Ansell, Fiona Gibson and David Salt, published 2016 by ANU Press, The Australian National University, Canberra, Australia. 